Genocide, Indian Policy, and Legislated Elimination of Indians in Canada

\author{
Pamela Palmater \\ Department of Politics and Public Administration, Ryerson University
}

aboriginal policy studies Vol. 3, no. 3, 2014, pp. 27-54

This article can be found at:

http://ejournals.library.ualberta.ca/index.php/aps/article/view/22225

ISSN: $1923-3299$

Article DOI: http://dx.doi.org/10.5663/aps.v3i3.22225

aboriginal policy studies is an online, peer-reviewed and multidisciplinary journal that publishes original, scholarly, and policy-relevant research on issues relevant to Métis, non-status Indians and urban Aboriginal people in Canada. For more information, please contact us at apsjournal@ualberta.ca or visit our website at www.ualberta.ca/nativestudies/aps/.

UNIVERSITY OF ALBERTA

FACULTY OF NATIVE STUDIES
Aboriginal Affairs and

Northern Development Canada

Affaires autochtones et Développement du Nord Canada 


\title{
Genocide, Indian Policy, and Legislated Elimination of Indians in Canada
}

\author{
Pamela Palmater \\ Department of Politics and Public Administration, Ryerson University
}

\begin{abstract}
The primary objective of early Indian policy was to ensure the eventual disappearance of Indians - a goal which has not changed in hundreds of years. The registration provisions in the Indian Act will achieve this goal through entitlement criteria, which ensures legislative extinction after two generations of marrying out. This has resulted in two separate legal categories offederally recognized registrants: status and non-status Indians, where membership in one group or the other determines access to essential services, band membership and more. The denial of federal recognition to non-status Indians has also resulted, in some cases, in the erosion of Indigenous identity, culture, and communal connection. Court-based remedies have done little to address these ongoing injustices and Canada has shown little interest in a significant policy change.
\end{abstract}

\section{Introduction}

What greater intrusion can there be than the arrogance of assuming the right to tell another people of another culture and tradition who is and who is not a member of their community and who can and cannot live on their lands. (Paul 1999, i)

Since time immemorial, Indigenous peoples living on Turtle Island (what is now referred to as North America) have enjoyed all the benefits, rights, obligations, and responsibilities attached to their identities as Mi'kmaw, Mohawk, or Cree peoples. ${ }^{1}$ While each traditional Indigenous Nation was unique and had very diverse laws, governments, knowledge systems, languages, and cultures, at a very broad level, they shared some commonalities. Traditional Indigenous Nations like the Maliseet, Ojibway, and Anishinabek viewed their own identities as inseparable from the land, water, sun, moon, plants, and animals. Indigenous languages represented more than mere words or means of communication (Battiste 2002; Battiste and Henderson 2000). The very place names given to specific lands, waters, and territories held within them important information about how the land was to be used, the navigability of certain waterways, historical knowledge about its traditional use, and important rules relating to protecting the space for current and future generations (Battiste

1 The terminology I use to refer to Indigenous peoples will correspond with this particular legal and policy context. I prefer to use the term "Indigenous" to reflect the diversity of Indigenous Nations, communities, and peoples, such as the Mi'kmaq, Maliseet, or Mohawk. However, I will use the term "Indian" when referring to the relevant legislative provisions, and the term "Aboriginal" for constitutional or related policy documents. Similarly, I will refer to the term "Indigenous Nation" to mean traditional Indigenous Nations like the Mi'kmaq, and the term "First Nation" or "Indian band," depending on the specific legislative or policy context. This article is not specific to either the Métis or the Inuit.

aboriginal policy studies, vol. 3, no. 3, 2014 
2002; Battiste and Henderson 2000). The names of children could also foster connections to generations of ancestors who had performed key roles in their Nations, like defending traditional territories, negotiating important peace treaties with other Indigenous Nations, or expressing some trait specific to a particular ancestor (Alia 1994). Indigenous identity is so bound up in culture, language, territory, family, community, and history that the denial of any one of these factors can have traumatic effects on an individual's identity and sense of self (Churchill 2010; Fiske and George, 2006; Fontaine 2010; Haig-Brown 1988; Miller 1996; Reagan 2010).

Although the period of North American colonization by Europeans has been relatively brief in comparison to the many millennia that Indigenous peoples have occupied these lands, the impact of that time has been devastating (Neu and Therrien 2003; Royal Commission on Aboriginal Peoples [RCAP] 1996; Moses 2008; Wolfe 2006). In roughly five hundred years, settler governments have managed, physically, culturally, and legally, to nearly wipe out Indigenous peoples (Neu and Therrien 2003; Palmater 2011a). Although historians often describe government policies of the day as well-intended assimilatory policies, the reality presents a much darker picture. The ultimate objective of early Indian policy was to access Indigenous lands and resources and, at the same time, to reduce the government's financial obligations to Indigenous peoples, and their methods were far from benign. From scalping laws to forced sterilizations, to residential schools and now the Indian Act's registration provisions (Indian Act 1985), the methods chosen to achieve those policy objectives have focused more on eliminating Indians than assimilating them (Neu and Therrien 2003; Palmater 2011b). Although some government officials have offered public apologies for some of Canada's past actions against Indigenous peoples, other government officials have countered those apologies with denials about the degree of harm caused, the financial cost of those apologies, and even of Canada's colonial history (Aboriginal Peoples Television Network [APTN] National News 2011; Barrera 2009; Macleans 2008; Harper 2008). If the government denies that colonization even occurred in Canada, it is hard to imagine how it will ever come around to acknowledging that the process of colonization continues to wreak havoc on Indigenous peoples and threatens their very existence; and yet, that is exactly what needs to happen (Lawrence 2004; Palmater 2011a).

The subject matter of this article is not new. Indigenous lawyers, activists, politicians, and authors have been struggling for years with the colonial impacts on Indigenous identity, and how current legislation continues to negatively impact Indigenous Nations. The intended contribution of this article is to focus attention on the purposeful, heinous governmental intentions with regards to Indian policy versus the myths of benign neglect or policies gone wrong promoted by successive federal governments in Canada. To my mind, the barrier towards real, substantive change in the relationship between Indigenous Nations and Canada is the failure by Canada to stop framing Indians as a "problem" and to abandon their policy objective of eliminating Indians. No agreement, law, or program will ever reverse the legislative extinction trend unless and until Canada accepts that Indigenous peoples are not mere memories from a time gone by, but are in fact here to stay. 
My goal is for readers to see the facts for what they are, stripped of the political rhetoric that often clouds frank discussions that might lead to significant changes. Given the numerous sovereign Indigenous Nations in Canada, I cannot propose a one-size-fits-all plan for change. This article is less about the answer and more about the information needed to fully understand the problem. It's not a cultural defect that places Indigenous peoples at the bottom of socio-economic indicators - it is Canada's history of genocide, and its attempts to eliminate Indians, that still informs and directs modern Indian policy, and that has had such a devastating impact (Palmater 2011b).

To that end, this article will briefly review the history of colonization in Canada as it relates to the settler government's primary policy objective to eliminate Indians and the various means it has employed to achieve these ends. By necessity, this will be a very broad overview, but there are numerous historical sources one can reference for this kind of information (RCAP 1996; Deloria 2003). Similarly, the concept of genocide, its development in law and theory, and the various debates around the United Nations' criteria for identifying genocide, are all very important issues relevant to a much deeper analysis of genocide than I can provide here (Ellinghaus 2009; Jaimes 1992; Moses 2008; McDonnell and Moses 2005; Short 2010; Wolfe 2006; Woolford 2009). Even the term "genocide" must be decolonized and redefined in a way that reflects the lived realities of colonized Indigenous peoples. For the purposes of this article, I will use the United Nations' basic definition of genocide to outline, in very general terms, how Canada's policies can be viewed as genocidal. This is not an acceptance of the UN's highly criticized definition, but a basic starting point for discussion. ${ }^{2}$ This discussion will be followed by a brief analysis of the Indian Act as it exists today, and the rules relating to state definitions of Indigenous peoples that have divided them into many categories, like Status Indians (those recognized as Indians by Canada) and Non-Status Indians (those not recognized). ${ }^{3}$ These rules not only have racialized Indigenous peoples into a fictional race of "Indians," but also defined them in a way to ensure their legislative extinction over time. This has been accomplished by reducing the size of the federally recognized group (Status Indians) and increasing the size of those that are unrecognized (Non-Status Indians). ${ }^{4}$ Federal legislation has had a significant impact on the lives of individuals, families, communities, and Nations in very real ways that threaten their physical well-being, and legal and political status. This article will review the ways in which these threats occur, and the negative impacts on one's sense

2 I fully acknowledge that the United Nations General Council is a political body controlled by states, the most powerful or influential of which have their own histories of genocidal acts against Indigenous peoples, which they would rather minimize.

3 Even the term "recognized" is complex, given the federal and provincial government's inconsistent recognition of Non-Status Indians as "Indians" or "Aboriginal peoples" for the purposes of certain programs and services. However, it is a less complex term when used for constitutional Aboriginal and treaty rights, for example.

4 A more detailed analysis of the varied ways in which registration impacts Indigenous identity can be found in Palmater (2010), Lawrence (2004), and Garroutte (2003). 
of identity and belonging - even up to an inability to access the necessities of life-that lack of registration creates.

While the focus of this article will be on the specific harms experienced by Non-Status Indians by virtue of their exclusion from federal recognition as "Indians," the reality is that their exclusion has an impact on Status Indians too. This extinction policy carried out via legislation is still defended by Canada today, and invites an examination of why this is still the case. This article will end with a call for Canada to acknowledge:

- its problematic legal construction of "Indians";

- the racist design and implementation of laws based on racist ideas about Indian blood; and

- its biased policy design, done through an "Indian problem" lens.

A permanent and substantive change in Canadian law and policy is needed so that Canada can get on with the business of true reconciliation (redress and restitution) and Indigenous peoples can move forward with healing, rebuilding their families, communities, and Nations, and enjoying the good life as they themselves defined it - the kind of freedom and liberty that so many Canadians get to take for granted.

There are many related issues that cannot be covered in this article, due to time and space limitations. The impact of the Indian Act on Indigenous identity, in turn, has an impact upon the implementation of legal rights like section 35 Aboriginal and treaty rights; the varying entitlements available from federal and provincial programs; the impacts on urban/off-reserve versus on-reserve Indigenous peoples; and complex identity issues like identity transfers between Non-Status Indians and Métis peoples. Similarly, there is a much larger Indigenous political context at the national, provincial, regional, and tribal council levels that cannot be covered within the limited focus of this article.

\section{Canada's Genocidal History}

His Majesty's Council, do promise a reward of ten Guineas for every Indian Micmac taken or killed, to be paid upon producing such Savage taken or his scalp (as in the custom of America) if killed to the Officer Commanding in Halifax, Annapolis Royal or Minas. (Paul, D.N. 2007, 109)

It has been estimated that the amount of global land held by Europeans between the years of 1800 and 1914 increased from 35 percent to 84 percent (Neu and Therrien 2003). It is no secret that the underlying objective of Canadian Indian policy has been to get rid of Indigenous peoples through whatever means necessary, with a view to securing permanent access to Indigenous lands and resources for the settler population (Neu and Therrien 2003; van Krieken 2004; Woolford 2009). Given the large number of Indigenous peoples occupying vast territories internationally, colonial governments have come to see Indigenous peoples as a major problem. The same is true for Canada and the United 
States (Wolfe 2006; Woolford 2009; Jaimes 1992; Smith 2005). Duncan Campbell Scott, a former deputy superintendent of Indian Affairs who had a significant impact on the design of Indian policy in Canada, felt that "the Indians were a real menace to the colonization of Canada" (Titley 1986, 32). As a result, he decided that "[t]he happiest future for the Indian race is absorption into the general population, and this is the object of the policy of our government" (Titley, 34). Scott had hoped that "[t]he great forces of intermarriage and education will finally overcome the lingering traces of native custom and tradition" (34). In this way, not only would Indians disappear culturally through education in the European tradition, but would also disappear biologically through the encouragement of intermarriage and the corresponding legal disentitlement to Indian status (Titley 1986). While it would be very easy to blame these policy objectives on Scott, they were part of colonial design long before Scott's involvement in residential schools (Deloria 2003; Smith 2005; Churchill 2010; Wolfe 2006). Various means were employed by settler governments to achieve the disappearance of Indigenous peoples, such as their physical, cultural, and legal destruction (Smith 2005; Wolfe 2006; Ellinghaus 2009; Churchill 2010).

While early legislation created a special status for Indians and created reserves in which to contain them, this state of affairs was always seen as a transitional or temporary measure until the full and final assimilation of Indians into the body politic (Titley 1986). And, although colonial states like Canada have downplayed the level of violence employed in trying to eliminate Indigenous peoples, it is a fact that settler governments used various methods to destroy Indigenous peoples physically. These facts require us to consider the term "genocide," and Canada's directing hand or complicit role in committing genocide against Indigenous peoples (Woolford 2009; Ellinghaus 2009; Neu and Therrien 2003).

"Genocide" is defined in Article 2 of the United Nations Convention on the Prevention and Punishment of the Crime of Genocide (1948) as:

... any of the following acts committed with intent to destroy, in whole or in part, a national, ethnical, racial or religious group, as such:

a. Killing members of the group;

b. Causing serious bodily or mental harm to members of the group;

c. Deliberately inflicting on the group conditions of life calculated to bring about its physical destruction in whole or in part;

d. Imposing measures intended to prevent births within the group;

e. Forcibly transferring children of the group to another group.

Whether as a direct act, an attempt, a conspiracy to commit, or as a complicity, Canada has enacted laws and policies and taken actions that fall under every category of genocide listed above (Palmater 2012; Churchill 2010; Smith 2005). ${ }^{5}$ Scalping could fit under Article 2 (a); torture and abuse in residential schools under 2(b); modern funding policies that

5 Due to time and space limitations, this article does not include a review of the international case law on genocide. This type of legal analysis, together with an in-depth look at the historical development of the crime of genocide and its current theoretical debates will be the specific focus of a future article. 
knowingly impoverish, imprison, risk the lives of, or separate Indigenous peoples and communities could fall under 2(c); forced sterilizations of Indigenous women clearly fit under 2(d); and Article 2(e) matches residential schools and the current over-representation of Indigenous children in care (Boyer 2006; Churchill 2010; Palmater 2011b; Palmater 2012; Paul 2007; Smith 2005). Thus, the term "elimination" will be used in this article to describe the overall objective of Canadian Indian policy, as the term "assimilation" is too often affiliated with a sense of benign intent, such as well-intended policies "gone wrong" (APTN 2011).

"Loss of Indigenous cultures" is not quite an accurate way to put it; rather it is a deliberate obliteration. The "loss" is not the inevitable falling away of outworn customs in the face of unstoppable modern progress. The fact is that bureaucratic mechanisms are employed in the destruction of cultures, and bureaucrats, with their biases, confusions and intentions, have historically made choices and planned ways to undermine, control and in some cases destroy targeted populations (Neu and Therrien 2003, 8).

Part of the decolonization process for Indigenous and non-Indigenous peoples alike is to acknowledge the history of Canada-both the feel-good sentiments about peace and friendship and the darker side of the colonization process, which continues into the present day. This acknowledgment includes recognizing how we define, interpret, and apply both the law of genocide and the punishment for it (Moses 2008; Short 2010).

One of the most devastating outcomes of early Indian policy in Canada was the legalized murder of Indigenous peoples, sometimes for financial reward. Take the scalping bounties in Nova Scotia, for example, where Governor Cornwallis promised financial reward for every Mi'kmaw man, woman, and child killed (Paul, D.N. 2007). This had the effect of reducing the Mi'kmaw population by up to 80 percent (Neu and Therrien 2003). But very little is ever written about this aspect of Nova Scotia history; Cornwallis himself is still celebrated in Nova Scotia, where they even named a school after him (CBC News 2011). The Beothuk, originally from what is now known as Newfoundland, were vilified by settler governments as "dangerous and sub-human," and were "persecuted and murdered" (Marshall 1996, 5); the last known Beothuk person, Shanawdithit, died in 1829. Other methods of ensuring the physical destruction of Indigenous peoples included the use of "biological weapons" (American Medical Association [AMA] 1999, 2128; see also Eitzen and Takafuji 1997, 41617). Colonial troops in the 1700s would give communities of Indigenous peoples blankets that were infested with the smallpox virus, with the effect of reducing the populations of specific Indigenous Nations by upwards of 50 percent (AMA 1999, 2128).

Less direct ways of ensuring the physical destruction of Indigenous peoples included the willful neglect of Indigenous peoples suffering from tuberculosis (Public Health Agency of Canada 2007). In the early 1900s, Dr. Peter Bryce exposed the genocidal practices of government-sanctioned residential schools, where healthy Indigenous children were purposefully exposed to children infected with $\mathrm{TB}$, spreading the disease through the school population (Bryce 1922). This led to mortality rates of 30 to 60 percent amongst the 
children who were forced to attend those schools (Bryce 1922). Medical experimentation on Indigenous populations was common not only in Canada, but in the United States as well (Smith 2005, 109). Indigenous women of child-bearing age were subjected to forced sterilizations, often without their knowledge or consent (Boyer 2006, 79). Less obvious ways of destroying Indians physically were the laws that prevented Indians from leaving reserves to hunt and fish for food for their families, forcing them to depend on government rations that were rarely enough to sustain their communities (Indian Act 1985; Isaac 1993; Native Law Centre 1993; RCAP 1996; Venne 1981). In the words of scholar John Steinbeck, "The Indians survived our open intention of wiping them out, and since the tide turned they have even weathered our good intentions toward them, which can be much more deadly" (2002, 326). The residential school system, which damaged or destroyed Indigenous identities, languages, and cultures, was a form of cultural genocide intended to destroy the people (RCAP 1996; Smith 2005; Churchill 2010; Short 2010; van Krieken 2004). Whether intended to kill the Indian physically or kill the Indian within, countless colonial laws and policies have been purposefully designed to destroy Indigenous peoples all over North America.

Some policies, like the Indian residential school policy, combined both the physical and cultural destruction of Indians. The residential school policy was a federal policy that authorized the removal of Indigenous children from their families and communities, and forced them to live in residential schools where they were to unlearn the ways of their own peoples and be educated in the European tradition (RCAP 1996; Smith 2005; Churchill 2010; Short 2010; van Krieken 2004; Woolford 2009). There is no real way to ever measure the totality of the harms suffered in those schools, but the death toll alone is staggering. Some schools had a death rate of upwards of 80 percent, and it is estimated that, on average, 40 percent of the Indigenous children that were forced to attend those schools never made it out alive (Bryce 1922).

It is readily acknowledged that Indian children lose their natural resistance to illness by habituating so closely in the residential schools, and that they die at a much higher rate than in their villages. But this alone does not justify a change in the policy of this Department, which is geared towards a final solution of our Indian Problem (Erasmus 2003, 4, quoting Duncan Campbell Scott, former deputy superintendent of Indian Affairs; emphasis added).

For many years, Indigenous peoples were forced to keep quiet about the torture and neglect that occurred in those schools, while governments and church officials covered up what was really happening (Churchill 2010; Erasmus 2003; Fontaine 2010; Haig-Brown 1988; Miller 1996; Regan 2010). Too many of these children, while surviving the schools, suffered unspeakable forms of torture like sexual abuse, beatings, medical experiments, electric shocks, and starvation (Erasmus 2003, 5). To say that these children were being "civilized" is a gross misrepresentation of what was actually occurring in those schools. The federal objective for these schools was not just to "kill the Indian in the child": the policy ended up breaking the human in the child, if it didn't kill him/her outright (Trevithick 1998, 
59). Assimilation, when conducted in such a rapid and aggressive manner as with residential schools, is the equivalent of elimination (McDonnell and Moses 2005). If cultures are the lifeblood of human social groupings, then destroying the lifeblood of the group is the same as destroying the group (Churchill 2010; McDonnell and Moses 2005; Smith 2005; Short 2010). However, Indigenous peoples were not dying off fast enough to accommodate the speedy settlement of their territories, nor were their legal claims to sovereignty and land so easily dismissed. And so, legislation was designed to ensure their extinction in law as well.

\section{Eliminating the "Indian Problem" in Canada}

I want to get rid of the Indian problem ... Our objective is to continue until there is not a single Indian in Canada that has not been absorbed into the body politic and there is no Indian question, and no Indian Department, that is the whole object of this Bill. (Duncan Campbell Scott, as quoted in RCAP 1996, 183)

The Indian Act contains laws designed to define, control, and ultimately eliminate federally recognized Indians in Canada (Indian Act 1985; Palmater 2011a). From its original enactment as the "Indian Act" in 1876 to its current version, little has changed in terms of the level to which Canada still controls Indians and their reserve lands (RCAP 1996). ${ }^{6}$ At Confederation, the federal and provincial governments divided up core areas of jurisdiction in the Constitution Act, 1867. Canada reserved for itself jurisdiction with regards to "Indians and lands reserved for the Indians" (Constitution Act 1867, s.91 (24)). Canada has since interpreted this jurisdictional head of power to include the right to define Indians and to control every aspect of their lives. The Indian Act, 1876 was created to amalgamate all pre- and post-confederation legislation with regards to Indians and bring their control under the full jurisdiction of the federal government (Titley 1986). Today, the Act defines who can be registered as Indians; who can be members of First Nation communities (Indian bands) ${ }^{7}$ who has the right to live on reserve; how reserve lands are to be used; how each community is to be governed; the powers granted to community leaders (Chief and Council); and even how property is to be dispersed upon the death of an Indian (Indian Act 1985). It is comprehensive in that it touches nearly every aspect of Indigenous life as individuals, families, communities, and Nations (Lawrence 2004; McIvor 2009; McIvor 2010; Palmater 2011; Palmater 2013; Paul 1999).

One of the most effective ways of accomplishing the legal elimination of Indians has been through the federal determination of who is and who is not an Indian. Section 6 and

6 It should be noted that the first piece of federal legislation concerning Indians was enacted in 1868 as An Act providing for the organisation of the Department of the Secretary of State of Canada, and for the management of Indian and Ordnance Lands, S.C. 1868, c. 42. The Indian Act followed shortly thereafter, in 1876.

7 The Act includes a provision that allows bands to enact their band membership codes. Some bands have enacted their own codes and altered the criteria for membership. For a detailed discussion of the variance between band membership codes, see Palmater (2011). 
7 of the Indian Act lay out the criteria for such federal recognition. A "registered Indian" is more commonly referred to as a "Status Indian," although the latter is not referenced in the Act. Those Indigenous peoples who are denied registration status are referred to as "nonstatus Indians," also known as "ghost people" for their lack of rights and legal recognition (Paul 1999, 1). Indians can be registered upon application to the Registrar, together with the submission of various documents to prove descent from parents and/or grandparents who are either registered or entitled to be registered as Indians (Indian Act 1985, s.2). These documents often include long-form birth certificates and marriage, death, or adoption records. The Registrar has a great deal of discretion in the final decision as to whether an individual can be registered or not and has, in some circumstances, granted registration status to individuals due to litigation settlements, appeals, and/or simple advocacy by Aboriginal organizations. ${ }^{8}$ That being said, Indian and Northern Affairs (INAC) has and continues to apply the registration provisions strictly against all applications, and against the majority of Indigenous peoples in Canada, creating a group of Non-Status Indians expected to increase as status Indians decrease (Clatworthy and Smith 1992; Clatworthy 1994; Clatworthy 2001c; Lawrence 2004; Magnet 2003). The ways in which this has been accomplished have evolved over time, with rules which excluded Indian women, illegitimate children, and adoptees, but the result is the same-the legislative extinction of Indians and their communities within predictable timeframes (Clatworthy 1994; Clatworthy 2001a; Clatworthy 2001b; Clatworthy 2001c; Clatworthy 2003; Clatworthy 2004; Clatworthy 2005; Clatworthy and Smith 1992; Lawrence 2004; Palmater 2011a; Paul 1999).

Since the first Indian Act in 1876 until 1985, the criteria for federal recognition as an "Indian" was largely based on a one-parent descent rule-so long as descent was from a male person of Indian blood (Sharon McIvor and Jacob Grismer v. Canada 2010, para 7). This meant that male Indians were guaranteed to be recognized as Indians, and even their non-Indian wives (and children) would be recognized as Indians by the government (Indian Acts 1867-2010; Indian Act, 1951, s.11). The only exception to this rule was enacted in 1951, when the double mother clause (DMC rule) provided that male Indians, whose mother and paternal grandmother were only Indians by virtue of having married an Indian, could lose their status at age twenty-one (Palmater 2011a, 19, 31, 43, 102, 137, 141). Less than two hundred males ever lost Indian status, as the DMC rule was repealed in 1985 and at least 285 First Nations had already obtained an Order-in-Council from INAC to be exempt from the rule (Palmater 2011a). Indian women, on the other hand, were at risk of losing their Indian status by a variety of means. The most common way was for an Indian woman to marry a non-Indian man. ${ }^{9}$ Unlike their male counterparts, their non-

8 Information obtained in 2011 from a senior employee of the Native Women's Association of Canada explained in detail the level to which the Registrar has granted status to individuals based on advocacy by NWAC or litigation settlement.

9 It must be kept in mind that a "non-Indian" man could include an Indigenous person from the United States, an unregistered Indigenous person, or a Métis or Inuit person. The non-Indian reference means anyone who was not registered as an Indian. 
Indian spouse did not gain Indian status but the Indian women lost hers instead, as did her children (Indian Acts 1876-2010). This loss of Indian status was permanent under section 12(1)(b) of the Indian Act 1951, as there was no provision (pre-1985) for Indian women to be reinstated upon divorce from her non-Indian husband or widowhood. The same was true for any children she had. "This 'bleeding off' of Native women and their children from their communities was in place for 116 years, from 1869 to 1985" (Lawrence 2004, 55). Approximately 16,000 women lost their status, and tens of thousands of children were also affected.10

Although section 12(1)(b) was repealed and replaced with a new registration scheme in 1985, there were other ways in which Indian women were discriminated against and excluded from Indian status. For example, pre-1985, the illegitimate children of a male Indian could be registered as Indians if the children were also male. Female illegitimate children were excluded. The illegitimate children of female Indians were entitled to be registered as long as no one protested the registration. Unfortunately, Indian agents often automatically protested the registration of illegitimate children, and many children were excluded. Even after these provisions were repealed, post-1985, with Bill C-31, the type of registration status assigned to illegitimate children can still vary based on whether or not they are male or female. For example, the illegitimate male child of a male Indian would have always been registered, so post-1985 both the father and son would be registered under section 6(1)(a)-often referred to as the "original" group. The female child would be considered a new applicant, and so be assigned section 6(2) status - the primary difference between the two sections is that section 6(1) Indians can transmit their Indian status to their children regardless of who they marry, whereas 6(2) Indians cannot.

Bill C-31 also included sweeping changes: the privileged positions of Indian men and their non-Indian wives were protected; the provision that allowed for the registration of illegitimate children of women was repealed; and bands were allowed to assume control over their own membership lists (Indian Act 1985). This gave the appearance that the discriminatory laws from pre-1985 no longer applied. However, despite the past versions of the Indian Act no longer being in force, the Registrar still applies them against all new applications that are submitted (Palmater 2011a). ${ }^{11}$ Bill C-31 went far beyond the issue of gender discrimination and created a new provision in section 6(2) called the secondgeneration cut-off rule. This new rule means that, after two generations of out-marriage, both men and women will lose Indian status. Section 6(2) was referred to as a "one-quarter blood" rule and modeled after the DMC rule, but meant to apply to both men and women for the purposes of their "future exclusions" (Groves 2011,3-8). However, it is more accurately described as a "half-blood" requirement because anyone with less than 50 percent blood

10 Statistical information received via Access to Information and Privacy request made to Indian and Northern Affairs Canada (INAC).

11 In order to determine the eligibility of the applicant, the Registrar still applies the old Indian Act entitlement provisions according to dates of birth, marriage, and so forth of the applicant's family members (those from which he/she descend). In this way, the old discriminatory provisions still impact applicants today. 
quantum (a legal fiction created by INAC) would not be entitled to registration ${ }^{12}$ (Groves 2011; Palmater 2011a). These ideas were considered carefully in 1982, prior to the passage of Bill C-31, when then-Minister John Munro distributed a discussion paper that explored the linkages between "blood quantum" and "descent-based rules" for the determination of Indian status (Groves 2011, 7). The idea was for "Government to have some form of control over its expenses" in relation to Indians and so they went with a "nominal 'halfblood' cut-off" (Groves 2011, 7-8). As the minister explained, "[t]he stricter registration on reinstatement and first time registration was based on the consideration of a declining affinity past the second generation without status, and recognition of the need to restrain the cost of reinstatement" (Groves 2011, 11).

Bill C-31 - while attempting to remove sexual discrimination-did not disturb the fundamental "assimilation" model under-writing prior Indian Act regimes: the idea that race and culture are strongly linked, and that one has to maintain a certain (and largely predominant) percentage of Indian descent to remain an Indian (Groves 2011,3).

Canada's ultimate priority with regards to Indian registration remains their legislative extinction over time and the perceived associated financial gains that attach to reduced numbers of Indians.

Even Bill C-3, the most recent Indian Act amendment, and which followed the McIvor case, did little to address gender discrimination. In fact, it created new forms of discrimination to limit the number of Indians who could be registered.$^{13}$ One of its anomalies is that the second generation cut-off rule is applied to descendants of Indian women who married out that were born prior to 1985-a retroactivity not applied to males (Palmater 2011a). Although not specifically challenged in the McIvor case, Canada vehemently defended its use of the second generation cut-off rule (half-blood rule) as being necessary to "retain registration as a means of continuing the federal government's relationship with individuals with sufficient genealogical proximity to the historical population with whom the Crown treated or for whom reserves were set aside" (Palmater 2011a, 122-23). In other words, Canada's view of Indigenous peoples remains frozen in time at the period of contact, and every subsequent generation of Indigenous peoples becomes more and more remote from the original group of Indigenous peoples at contact. While Canada is not the only state to have ever used blood quantum, it is has the dishonor of being the last.

Canada is now the sole British settler state to maintain a national statutory framework that attempts to determine the legal status of the majority of its aboriginal population on essentially race-based criteria. This framework or paradigm rests on

12 While I have referred to this legal fiction as "notional blood quantum," it has also been referred to as "nominal 'half-blood' cut-off."

13 An Act to promote gender equity in Indian registration by responding to the Court of Appeal for British Columbia decision McIvor v. Canada (Registrar of Indian and Northern Affairs) 2010 R.S.C. c.18 [Gender Equity in Indian Registration Act], commonly referred to as Bill C-3. 
the two-fold presumption that (a) the state, as opposed to the aboriginal groups themselves, should determine the criteria for group membership, and; (b) that the "race-quantum" of a person, as represented through the degree or percentage of biological connection to ancestors presumed to be of the same race, is the main or defining agent in the transmission of distinctiveness, and entitlement to (or need for) a matching legal status (Groves 2011, 4).

When considering the larger legal, political, and social landscape, Canada is clearly out of step with modern laws and social thinking about Indigenous peoples, legal rights, and identities (Powley 2003, 32; RCAP 1996, 166).

\section{Extinction by Policy}

Chief: I should not feel happy if I was not to mess with some of my children that are around me-those children that we call the Half-Breed-those that have been born of our women of Indian blood. We wish that they be counted with us, and have their share of what you have promised.

Governor: They must be either white or Indian. (Jamieson 1978, 41)

All Indigenous peoples have been affected by federal policies requiring strict dividing lines based on European conceptions of race. The ability to restrict the number of status Indians so as to ensure their extinction over time has also evolved outside the scope of the legislation, through internal policies created by INAC. Although the Supreme Court of Canada (SCC) found the Inuit to be "Indians" for the purposes of section 91(24) of the Constitution Act, 1867 (Re Eskimo, 1939), Canada amended the Indian Act to specifically exclude them from registration (Indian Act, 1951). Similarly, Métis people who took scrip are also excluded from Indian registration (Alberta [Aboriginal Affairs and Northern Development] v. Cunningham 2011, para. 7). ${ }^{14}$ These acts were not mandated by law, but were policy choices designed to eliminate the Indigenous populations. The most glaring example of this is what is commonly referred to as unknown, unstated, or unrecognized paternity. This policy was introduced after the 1985 Bill C-31 amendments to the Indian Act (Mann 2005, 5). Prior to 1985, there was a legal presumption in the Act that the father of an un-wed mother was an Indian and thus the child could be registered as the child of two Indians (Indian Act 1951). The only exception to this legal presumption was if the band, Indian agent, or third party filed a protest with the Registrar asking that the child's name be removed because the father was a non-Indian. ${ }^{15}$ This legal presumption in favour of Indian paternity was removed from the Indian Act in 1985.

14 That being said, the Bill C-31 and Bill C-3 amendments to the Indian Act's registration provisions means that some people who identify as Métis are now entitled to be registered as Indians. This may or may not impact their eligibility to belong to various Métis groups, organizations or communities. 
Although not as well-known, INAC's unstated paternity policy nevertheless has an impact upon tens of thousands of Indigenous children born to unwed mothers. It has been estimated that, between 1985 and 1999, there were over 37,000 children born to section 6(1) Indian mothers who, due to unstated paternity, were registered in the lesser category of section 6(2), and that there were over 13,000 children born to section 6(2) Indian women who were not registered at all (Clatworthy 2003, 248; Palmater 2011a, 107). The denial of a child's registration could be caused by the simple act of the status Indian father refusing to sign the application form (Clatworthy 2003, v). While 50 percent of all cases of unstated paternity are considered "intentional" (i.e., the mother refuses to disclose name of father), 50 percent are "unintentional" (Clatworthy 2003). The reasons vary for not stating paternity, and can include serious privacy and safety issues like rape, incest, and domestic violence. However, the administrative denial of registration for factors out of the control of the mother or child is troubling from a public policy and gender perspective. This policy disproportionately affects single Indian mothers, who are already a vulnerable group, but is further complicated by the application of the second-generation cut-off rule on top of an already discriminatory policy (Clatworthy 2003, 3; Palmater 2011a, 107).

Despite the fact that Canada removed the presumption in favour of Indian paternity for unwed mothers in 1985, a counter presumption was never enacted. In other words, although Canada removed the legal presumption of Indian paternity for the children of unwed Indian mothers, it did not replace it with a provision making a specific legal presumption that unstated fathers were non-Indian (Palmater 2011a, 43, 107-108). The fact that the Registrar processes applications this way is actually a policy choice that is well outside the parameters of INAC's authorizing legislation (Sullivan 2007). It also runs counter to the most basic principles of statutory interpretation: "legislation that interferes with the rights of subjects strictly construed; any doubts concerning the application of such legislation are resolved in favour of the subject and the preservation of his or her rights" (225). This is the same interpretive principle that applies to legislation dealing with social welfare, Aboriginal rights, human rights, and cultural rights (225-36).

There are other ways of assimilating Indians: the Sixties Scoop, for example, saw many Indigenous children taken from their families and permanently adopted out into non-Indigenous families (Bennett, Blackstock and De La Ronde 2005, 19). Many of those children struggle today to determine the identity of their birth parents, and are not always able to find their home communities or register as Indians-a process that requires them to access vital birth information related to their parents and home communities (Paul, $\mathrm{P}$. 1990). Still other applicants for Indian status can be denied registration if they are unable to meet INAC's evidentiary requirements, which can be difficult if relatives have passed on or vital records have been lost or destroyed. Another, lesser-known path for Indigenous peoples to become Non-Status Indians is through "omission" (Cornet 2003a, 129-130; Cornet 2003b). From 1876 to 1951, Indians were identified (if at all) by Indian agents and federal officials, who maintained informal lists of those Indians affiliated with bands or treaties-neither of which were comprehensive (Cornet 2003a, 129-30). The names 
that appeared on these band lists were later used to determine the formal register (list of registered Indians) created in 1951. "Many Aboriginal communities and individuals were missed in the initial attempt to create the first Indian Register, and thus became non-status Indians by omission" (Cornet 2003a, 130). Newly created band lists were supposed to be posted for individuals to reconcile their inclusion but, as RCAP noted, many names were excluded:

The names of many people who ought to have been on the band lists or the general lists were never added. They may, for example, have been away from the reserve when the band lists were posted. In remote places, especially where people still practiced a subsistence lifestyle, people could have been away on hunting parties, fishing or traplines. Such people were also the least likely to have been able to read in the first place. Some people were opposed to any form of registration, seeing it as a derogation from the historical status of Indian nations (RCAP 1996, 312, as cited in Cornet 2003a, 130).

There is no way to determine fully how many people were erroneously excluded from band lists, or how many of their children and grandchildren were excluded consequently. These individual actions by Indian agents were part of the larger policy scheme designed to purge band lists and reduce financial obligations to Indians. In the end, all paths lead to the legislative extinction of Indians, and the existence of Non-Status Indians are the first signs of this eventuality.

\section{Why Does Indian Status Matter?}

This is the problem when legislation is introduced that controls a group's identityonce created and established, it cannot simply be undone. You cannot put the genie back in the bottle again-you have to deal with it. (Lawrence 2004, 230)

Decolonized ways of thinking about Indigeneity focus on conceptions of identity, which stem in turn from Mi'kmaw, Mohawk, and Maliseet ways of thinking. So why, then, should Indian status matter? It matters because there is a practical reality to Indigenous identity that has shaped the minds, beliefs, laws, and politics of contemporary Indigenous communities. The idea that Indian status shouldn't matter or shouldn't determine Indigenous identity does not address the fact that Indian status does impact individuals and communities in profound ways. The lived reality of thousands of Indigenous peoples is that they are excluded from communal acceptance by virtue of this legislative regime-which some consider to be a form of "banishment" (McIvor v Canada 2010, para. 126; Sandra Lovelace v Canada 1981). There is a perception that those who have status have never had to worry about their more authentic Indigenous identity because it has never been threatened legislatively (Lawrence 2004). On the other hand, Non-Status Indians who have been legally excluded from recognition, denied band membership in their home communities, and discriminated against for not being Indian enough, have had not only to focus on trying to maintain their

authentic Indigenous identities, but also on official legislative recognition status (Lawrence 
2004, 217-18; Palmater 2011a, Palmater 2013). The colonization of many generations of Indigenous peoples has deeply embedded federal recognition as a form of identity, the withholding of which has created legal, political and social divisions, and insecurity in many communities. With the increasing focus on decolonization (Alfred 2009a; Alfred 2009b; Corntassel 2005), there is a growing recognition of the specific harms that has been inflicted by federal control over Indigenous identities. Decolonization is a long process, however, and there is a need in the meantime to understand how exactly Indian status, or the lack thereof, affects Indigenous peoples in Canada today.

Indian status, or its lack, not only impacts one's economic, political, and legal rights, but also one's physical and mental well-being. Indian status often determines whether an individual qualifies for various federal programs and services like on-reserve housing, social assistance, health benefits, and post-secondary education assistance. Despite legislative entitlements, the majority of federal Indian programs are both purposefully and chronically underfunded, resulting in Indians being the most impoverished in Canada, and having both the highest rates of preventable diseases, suicides and injuries, and the lowest rates of education and employment in the country (Palmater 2011b; RCAP 1996). They are more likely to go to jail than get a high school education, and they live from seven to thirty years less than the average Canadian (Palmater 2011b; RCAP 1996). The denial of essential social programs and services that comes with the denial of Indian status has significant consequences for more than just non-status Indian individuals.

As adults, these children will be primary caregivers to their aging kin members. If they are denied access to First Nations land and resources, they will not be able to fulfill their traditional obligations in a meaningful way. Without the support from federal funding, small First Nations are unable to provide for their citizens. Denial of status to the third generation in the small communities means the First Nations will not have funds to support children who in the future would be supporting the elders (Fiske and George 2006, 44).

Some First Nations in this country are already in a state of emergency caused by a lack of safe drinking water, sanitation, and housing-which is the direct result of Canada's purposeful and chronic underfunding of essential services (Palmater 2011b). Non-Status Indians are excluded from accessing even these basic, under-funded essential programs and services. And so, Non-Status Indians, not only suffer from identity insecurity, but they, their caregivers, and those they care for may also suffer from food, water, and housing insecurity.

One of the common misconceptions about Indian status is that individuals only seek to be registered for the purposes of gaining some sort of financial benefit. True, one hears anecdotally of cases where individuals with no connection to their culture or community have sought out access to federal programs and services, but these are the exception. ${ }^{16}$

16 Katherine Carlson, National Post, "How the O'Leary's and 20,000 other Newfoundlanders were declared Mi'kmaq" (Oct.1, 2011), online: National Post < http://news.nationalpost.com/2011/10/01/how-theo\%E2\%80\%99learys-and-20000-other-newfoundlanders-were-declared-mi\%E2\%80\%99kmaq/>. 
However, the research indicates otherwise. After the passage of Bill C-31, which reinstated as Indian some of the women who had lost their status, over 70 percent of those surveyed by the Native Council of Canada (now the Congress of Aboriginal Peoples) wanted their Indian status and band membership to regain a connection with their culture, but not for the purposes of reserve-based benefits like residency (Lawrence 2004, 69). When asked why they applied for Indian status, 41 percent cited personal identity and 21 percent cited culture and belonging (Paul, P. 1990, 83-84). Outsiders often criticize reserves as being harmful, but for many, these communities are what have held Indigenous peoples together in the face of brutal genocidal policies. Some even consider them to be the last stand against the complete erosion of Indigenous cultures, languages, and identities (Lawrence 2004, 217; Alfred 2009a; Alfred 2009b). Canada has defined and limited who can be Indian and who can access reserve, treaty, and other Indigenous lands. In so doing, the legislative framework that seeks to eliminate Indians over time will also have the effect of dispossessing Indians from their communal, and even Nation-based, lands. In this way, Indian status acts as a two-edge genocidal sword intending to destroy the identities, cultures, and landholdings of those it defines; but to remove status, without any protections in its place, would also threaten to destroy Indigenous groups and their state-defined landholdings-under Canadian law (Milloy 2008, Palmater 2011a.).

All individuals look for recognition and confirmation of their individual and communal identities, and sense of belonging, in others. "They search for a sense of self in relation to fellow members of the community and their way of life. Viewed in this manner it is easy to see how those individuals who, for whatever reason, will not obtain Indian status (the legislative shared identity) will not feel as if they were part of the community" (Paul, P. 1999, 15). Decolonization is a long, difficult path that many have not yet started to engage with. Some individuals will have internalized these state definitions as determinative of who they are and where they belong. Of all the tangible and intangible benefits associated with Indian status, the impact that is felt most strongly is the exclusion from one's cultural identity and community (Lawrence 2004, 55; Sandra Lovelace v Canada 1981; McIvor 2010). Indigenous women and their descendants are over-represented in this group, and have often spoken of the pain associated with what has been referred to as "statutory banishment" (Lawrence $2004,55)$. Such banishment also takes the form of denied political rights, like the right to be a band member, run for elected position, vote for chief and council, participate in referenda related to reserve and other land holdings, and decide on the fate of their extended families, communities, and Nations. Even the right to participate in treaty, land claim, and selfgovernment negotiations can be a political right limited by a lack of Indian status and/or band membership. Indian status rules are wielded by federal and provincial governments as barriers to accessing constitutionally protected rights.

Lack of access to communities, elders, and traditional knowledge-holders resulting from lack of status is part of the "multigenerational legacy" of colonization (Alfred 2009c, 50). If a grandmother lost her status by marrying a non-Indian, and she and her children are then separated from the community, the child may not learn his Indigenous language. 
Several decades later, when one or both are reinstated, the children and grandchildren have missed out on learning their language and can't pass it on to future generations. In this way, the cultural trauma attributed to loss or exclusion from Indian status may not be easily reversible, if at all (Fiske and George 2006). The impact on culture is most evident in the fact that, currently, only three of the fifty Indigenous languages spoken in Canada are safe from immediate extinction (Natural Resources Canada 2009). There are those who liken the loss of culture attributed to exclusion from Indian status as similar to the loss of culture resulting from residential schools or the Sixties Scoop ${ }^{17}$ (Paul 1999, 2-3). No one would hold it against a residential school survivor or a Sixties Scoop survivor for having lost their ability to speak their Indigenous language or for not knowing their traditional ceremonies. Yet, the same consideration is not often extended to the descendants of Indigenous women who lost their Indian status and were banished from the reserve. Given that the registration provisions, residential schools, and the Sixties Scoop were all genocidal acts imposed by settler governments, it seems unjust to blame the victims for the policies designed to eliminate them. This is the complex, difficult reality of colonial laws designed to assimilate and eliminate Indigenous peoples (Short 2010; van Krieken 2004; Wolfe 2006; Woolford 2009; Ellinghaus 2009).

Indian status also affects legal rights, especially those related to Aboriginal and treaty rights. Federal officials/departments have designed policies regarding the identification of treaty beneficiaries and Aboriginal rights holders in a way that parallels the stringent rules for Indian status (Palmater 2000). Provincial enforcement agencies often ensure that their enforcement policies follow federal Indian status policies as well (Palmater 2000). This has the effect of incorporating a federal entitlement scheme into historic treaties that were signed long before the Indian Act was even created. Take for example, the SCC decision in Marshall I, where the right to fish eel and sell it for commercial purposes was recognized as a treaty right protected in section 35 of the Constitution Act, 1982 (R. v. Marshall, 1999). All of the violence, protests, enforcement activities, and legal proceedings that followed the SCC "win" overshadowed the issue facing Non-Status Indians. According to the Department of Fisheries and Oceans (DFO), the only people legally entitled to exercise the treaty right to fish and sell it were Status Indians who were members of a band-what they referred to as the "modern manifestation" of historic communities (House of Commons 1999). This was interpreted to mean that Non-Status Indians, non-band members, and their representative political organizations were excluded from post-Marshall negotiations, discussions, information sessions and, ultimately, from commercial fishing arrangements with the DFO (Palmater 2000). By unilaterally tying treaty status to Indian status, the federal government could ensure that when Status Indians are legislatively extinct, so too would be the treaty beneficiaries and any financial obligations to them. Provinces have also used state definitions to deny Aboriginal and treaty rights to Indigenous peoples, including

17 I fully recognize that not all experiences were the same (as between Indian Act exclusion and residential schools) and that the comparison is not on the extent of the suffering (for there is no comparison) but on the similar outcomes with regard to cultural and/or identity loss, interruption, or interference. 
hunting, gathering, and the use of timber to name a few (MacIntosh 2009; Palmater 2003). ${ }^{18}$ The denial of Aboriginal and treaty rights to Non-Status Indians is also a serious blow to their ability to maintain their cultural connections, benefit from a healthy, traditional diet, and provide for their families - another nail in the coffin of Indigenous identity.

The psychological and physical impacts of colonization have also had a profound impact on the health and well-being of Indigenous peoples. Clearly the message has been "assimilate and be like us or suffer the consequences," and those consequences are severe (Alfred 2009, 43). Indigenous peoples have some of the highest suicide rates in the world (Lauwers 2011). Suicide is not a cultural trait however: instead, it is the most painful symptom of the absolute despair experienced by colonized peoples who are denied the ability to think, act, and live in an Indigenous way. When a people have felt a sense of self-hatred for multiple generations and can see no end to colonization in the near future, it becomes easier to understand how children as young as eight and nine years old would think about giving up their lives (Lauwers 2011). Previous studies have also noted that Indian women and their children who lost status from the pre-1985 marrying-out provisions suffer with identity problems because they feel "culturally different and often socially rejected by white society, yet they may not participate with family and relatives in the life of their former communities" (Jamieson 1978, 41). It is notable that just the threat of being evicted from one's home community has caused severe psychological and health problems and even resulted, in at least one instance, in a heart attack and death (Jamieson 1978, 72).

There is no amount of compensation that could ever be offered to provide full redress for the loss of cultures and languages, divided families, and communities, and the sense of well-being that goes along with acceptance (Paul 1990). This is how colonial policies are so effective at destroying cultures and why the crime of genocide is the best descriptor for the devastation these policies cause-for many generations after their application.

\section{Moving Forward}

We no longer need diseases, wars or scalping bounties to wipe out a people. Today, silent acquiescence by society towards the current legislation and policy towards non- status Indians is all that is necessary to bring about the extinction of these Aboriginal people. (Palmater 2000, 148)

Canada has kept First Nations so busy trying to survive and focus their energies on distractive political exercises that the core outstanding issues of treaty implementation, recognition of self-determination, and the return/sharing of Indigenous lands and resources remain unresolved. The primary differences between today and fifty years ago is that the gap between the well-being of Indigenous peoples and of Canadians is getting

18 Due to time and space limitations, this article will not be able to canvass the extensive case law dealing with provincial denial of Aboriginal and treaty rights or the trend in some cases towards limiting access to these rights to those who follow an "Indian mode of life"-another state-defined notion of what is an Indian. 
worse; Indigenous languages are becoming increasingly endangered; and the number of Non-Status Indians continues to increase. Canada has a history of deferring, deflecting, and denying responsibility for problems when it comes to Indigenous peoples (Palmater $2011 \mathrm{~b}$ ). The way forward in dealing with any of the issues faced by Indigenous peoples today, including the increasing number of Non-Status Indians, is to address the root problem: Canada's program of legislative and policy-based genocide. If that were to be addressed, then the chronic underfunding of essential programs and the over-representation of Indigenous peoples in jails, as wards of child and family services offices, and in funeral homes would stop. The theft and destruction of Indigenous lands and resources would stop. The federal laws and policies that create, define, and eliminate Indians out of existence would be repealed. Recognizing that none of this would happen overnight, implementing this change could be centered around several key short, medium, and long-term objectives specific to Indian registration and the core issues:

1. in the short term, the Indian Act be amended to put individuals back where they would have been, but for the discriminatory legislative definitions of Indian;

2. in the short-to medium-term, the official abandonment of Canada's genocidal elimination and assimilation policies; and

3. in the longer term, the full legal recognition and implementation of the Indigenous right to self-determination with the corresponding restitution of lands and resources.

There are very few (outside the federal context) who believe that the solution to any of the issues facing Indigenous peoples lies in further amendments to the Indian Act. At the same time, valuable lessons were learned in 1969 when Canada's White Paper on Indian Policy set out a plan to once and for all assimilate Indians, break-up reserves, and get rid of treaties by repealing the Indian Act (Government of Canada 1969). First Nations were clear when they said that this was not the solution:

Mr. Chrétien says, "Get rid of the Indian Act. Treat Indians as any other Canadians." Mr. Trudeau says, "Forget the treaties. Let Indians become Canadians." This is the Just Society? To the Indian people, there can be no justice, no just society, until their rights are restored" (Cardinal 1999, 25).

Simply repealing the entire Indian Act, without anything more, would cause more problems, not less. That being said, First Nations have also recognized that the Indian Act creates artificial divisions between siblings, families, and communities, and removes tens of thousands of Indigenous peoples from their Nations. As long as the Indian Act remains in existence, then it must be amended to comply with domestic and international Indigenous rights related to non-discrimination. The United Nations Declaration on the Rights of Indigenous Peoples (UNDRIP) specifically protects equality as between Indigenous men and women, and protects the right of individuals to belong to their communities. ${ }^{19}$ Thus, in

19 United Nations Declaration on the Rights of Indigenous Peoples, UNGA, 62nd Sess. UN Doc. A/ RES/61/295 (13 September 2007) [UNDRIP]. 
the short term, gender, age, and other forms of discrimination in relation to Indian status must be resolved. If it were possible for Canada to abandon its assimilation policies and formally recognize and implement Indigenous self-determination quicker than it could amend the Indian Act, then I would advocate for the former. Canada has never acted that quickly on its policy changes, however, and so amendments to the Indian Act are necessary in the short term.

In the short to medium term, Canada must officially abandon its policy of assimilation of Indigenous peoples. Canada's policies have changed very little and are still promoted as being in the best interests of Indigenous peoples, but the policies themselves have not changed. How can Canada advocate for the assimilation of Indigenous peoples on the one hand, and enter into self-government negotiations in good faith on the other? The problem is-it can't. That is why we see INAC negotiators demanding that a one-quarter blood rule (referred to as the "one-quarter ancestry" rule) be part of any citizenship code of selfgoverning First Nations (Palmater 2011a, 164-75). Self-government citizenship codes that merely reproduce the Indian Act status rules can hardly be said to do anything other than uphold the "status" quo. The "gradual destruction of the tribal organization" can no longer be the aim of Canada if the treaty relationship is to be respected (Jamieson 1978, 28). Canada must make a policy decision to get out, finally, of the business of defining, controlling, and eliminating Indians. If Indigenous peoples are expected to accept that Canadians are all here to stay on our territories, then it is long past the time when Canada accepted that Indigenous peoples are here to stay. Canada can and should work together with Indigenous peoples to create a new relationship-all that is currently lacking is the will.

Part of this new relationship in the long term is about Canada creating the legal, policy, and social space for Indigenous peoples to exercise their right to be self-determining and to recognize the jurisdictions and laws of Indigenous Nations. The right to determine the internal composition of each Indigenous Nation lies at the core of self-determination. The recognition of Indigenous self-determination is fundamental to Canadian-Indigenous relations; to the survival of Indigenous identities, cultures, and Nations; and to finally realizing justice in Canada. Canada has recently supported UNDRIP (albeit conditionally), which specifically recognizes the inherent right of self-determination and the right of Indigenous peoples to determine their own citizenship (UNDRIP, 2007). UNDRIP may go a long way towards addressing the sometimes deeply embedded colonial ideologies around Indigenous identity with which some communities still struggle. But even without UNDRIP, these rights are recognized in other international laws, declarations, covenants, and decisions. Indigenous peoples do not need any more "recognition"-what is required now is implementation. This does not require any new committee, organization, program, or table-it means going back to what worked: the Nation-to-Nation relationship. For some, this means a revitalization of their treaties, and for other it might mean negotiating a new treaty or agreement. Either way, the inherent sovereignty and jurisdiction of Indigenous Nations have never been displaced and should be the focus of inter-governmental relations on a go-forward basis. The original Nation-to-Nation relationship would and allow one 
another to develop their societies as they see fit-always keeping in mind the right of Indigenous Nations to be self-determining in all matters. To do otherwise ignores the fact that Indigenous sovereignty, jurisdiction, laws, rules, and customs relating to citizenship long pre-date contact and were never displaced by Canada's assertion of sovereignty.

\section{Conclusion}

It is quite clear from the research that there are many paths to becoming a Non-Status Indian. It would appear that there are many more ways to lose or be denied Indian status than there are to be so granted. This is not a matter of an identity policy gone wrong-it is, in fact, how the Indian Act was designed. The fact that the Act prescribes more ways to lose status than to receive it is proof that it was designed for the express purpose of getting rid of the "Indian problem" and assimilating them once and for all. The Act was never designed to create a group Indians for their own cultural protection; it was intended to identify and eliminate the "problem"-i.e., those standing in the way of accessing the vast lands and resources in Canada. The plethora of ways to lose or be denied status means that the population of Non-Status Indians will continue to increase, while demographic predictions about Status Indians paint a future of legislative extinction. This does not mean that Indigenous peoples will no longer exist. To the contrary, they have survived every genocidal law, policy, and action thrown at them, and are still here today. The Mi'kmaq, Mohawk, and Maliseet will still be here. The issue will be that Canada will not recognize those people as "Indians": i.e., those entitled to make "claims" for their territories, resources, Aboriginal, and treaty rights. If there are no more Indians, then, for the majority of First Nations in Canada, there will be no more band members. ${ }^{20}$ If there are no more band members, then there will be no more legal owners of those reserve lands (use and benefit interest), and the lands could escheat (revert) back to the Crown. Chief Bill Montour from Six Nations of the Grand River Territory calls this "the biggest land grab of the century" (Montour 2011).

The issue that seems to be of greatest importance to both Status and Non-Status Indians alike is the health and well-being of their Indigenous families, communities, and Nations. Indian status has not replaced traditional Indigenous identities, but it has affected the paths by which individuals can access and maintain those traditional identities. The denial of Indian status has had serious consequences on all the factors which determine one's health and well-being-recognition, acceptance, self-worth, familial and communal supports, access to language speakers and traditional knowledge-holders, and the ability to enjoy one's culture in community with their specific Indigenous Nation. Some Indigenous peoples have feelings of self-hatred and are more prone to suicide and self-destructive behaviours, due to the "colonially generated cultural disruption" (Alfred 2009, 42). Even the ability to provide for one's family through traditional hunting or fishing practices is often curtailed

20 Another implication has been the swell in Métis population numbers, some of who are Non-Status Indians seeking a recognized identity and when denied legal registration as an Indian, might turn to Métis identity as a solution. See Palmater $(2003,149)$. 
by whether one has Indian status and can mean the difference between feeding one's family healthy food from the land or being arrested and jailed. While the details of any policy or relationship can always be negotiated, the choice to take action is just that-a choice.

Both sides of this treaty relationship have an obligation to take action. Canada, for its part, must (1) create the legal, policy and social space for Indigenous peoples to exercise their right to be self-determining, (2) officially abandon the current federal assimilation policy, and (3) amend the Indian Act to eliminate gender and racial discrimination. Indigenous communities and Nations, for their part, must also take action to address the current inequities amongst their peoples, regardless of Canada's positions. Sovereignty and the right of self-determination can never be granted by another entity, nor can it be realized in a passive manner. Indigenous sovereignty must be asserted, protected, and acted upon every single day for it to be given effect. The process of decolonization is, admittedly, a difficult one, but one necessary for the survival of the next seven generations. Indigenous peoples have an obligation to learn their history, understand how colonization has impacted their ways of thinking and their understanding of identity and belonging, and start exorcising those colonial ghosts from their communities. If we can't forgive ourselves for suffering colonization, then decolonization can never get started. The sacrifices of our ancestors require that we, as Indigenous peoples, take positive steps to heal our communities and Nations and bring our lost people home. 


\section{Bibliography}

2011. "Halifax founder's name to disappear from school." CBC News, June 23. http://www. cbc.ca/news/canada/nova-scotia/story/2011/06/23/ns-halifax-cornwallis-schoolrename.html.

2011. "Saganash calls on Duncan to apologize over residential schools comment." APTN National News, October 27. http://aptn.ca/pages/news/2011/10/27/residentialschools-saganashduncan-apologize/.

Alfred, T. 2009a. Wasase: Indigenous Pathways of Action and Freedom. Toronto: University of Toronto Press.

-_- 2009b. Peace, Power, Righteousness: An Indigenous Manifesto. 2nd ed. Don Mills, ON: Oxford University Press.

-_-. 2009c. "Colonialism and State Dependency." Journal of Aboriginal Health 5: 42-60.

Alfred, T. and J. Corntassel. 2005. "Being Indigenous: Resurgences against Contemporary Colonialism." Government and Opposition 40: 597-614. http://dx.doi.org/10.1111/ j.1477-7053.2005.00166.x.

Alia, V. Names, Numbers, and Northern Policy: Inuit, Project Surname, and the Politics of Identity. Halifax: Fernwood Publishing, 1994.

American Medical Association [AMA]. 1999. "Smallpox as a Biological Weapon: Medical and Public Health Management." The Journal of the American Medical Association 281: 2127-37. http://dx.doi.org/10.1001/jama.281.22.2127.

Barrera, J. 2009. "First Nations leader demands meeting with Harper over 'colonialism' comment." The Gazette (Montreal), 1 October.

Battiste, M. 2002. Indigenous Knowledge and Pedagogy in First Nations Education: A Literature Review with Recommendations. Ottawa: Indian and Northern Affairs Canada.

Battiste, M., and H. J. Youngblood. 2000. Indigenous Knowledge and Heritage: A Global Challenge. Saskatoon: Purich Publishing Ltd.

Bennett, M., C. Blackstock and R. De La Ronde. 2005. "A Literature Review and Annotated Bibliography on Aspects of Aboriginal Child Welfare in Canada." The First Nations Child and Family Caring Society of Canada. http://www.fncfcs.com/sites/default/ files/docs/AboriginalCWLitReview_2ndEd.pdf.

Boyer, Y. 2006. "First Nations, Métis, and Inuit Women's Health." Discussion Paper Series in Aboriginal Health: Legal Issues, no. 4. Ottawa: NAHO.

Bryce, P. 1922. The Story of a National Crime: Being a Record of the Health Conditions of the Indians of Canada from 1904 to 1921. Ottawa: James Hope and Sons.

Canadian Bar Association. 2010."Bill C-3-Gender Equity in Indian Registration Act." http://www.nwac.ca/sites/default/files/imce/WEBSITES/201105-06/Bill\%20C-3eng1.pdf.

Cardinal, H. 1999. The Unjust Society. 2nd ed. Vancouver: Douglas \& McIntyre.

Carlson, K. B. 2011. "How the O'Leary's and 20,000 other Newfoundlanders were declared Mi'kmaq." National Post, October 1. http://news.nationalpost.com/2011/10/01/ how-the-o\%E2\%80\%99learys-and-20000-other-newfoundlanders-were-declared$\mathrm{mi} \% \mathrm{E} 2 \% 80 \% 99 \mathrm{kmaq} /$. 
Churchill, W. 2010. Kill the Indian, Save the Man: The Genocidal Impact of American Indian Residential Schools. San Francisco: City Lights Publishers.

Clatworthy, S. 1994. "Revised Population Scenarios Concerning the Population Implications of Section 6 of the Indian Act." Ottawa: Indian and Northern Affairs Canada.

-_- 2001a. "Bill C-31, Indian Registration and First Nations Membership." Ottawa: Indian and Northern Affairs Canada.

- - - 2001b. "Paternal Identity and Entitlement to Indian Registration: The Manitoba Context." Ottawa: Indian and Northern Affairs Canada.

- - - 2001c. "Reassessing the Population Impacts of Bill C-31." Ottawa: Indian and Northern Affairs Canada.

- — - 2003. "Factors Contributing to Unstated Paternity." Ottawa: Indian and Northern Affairs Canada.

- - - 2004. "Implications of First Nations Demography: Final Report." Ottawa: Indian and Northern Affairs Canada.

- - - 2005. "Indian Registration, Membership and Population Change in First Nation Communities." Ottawa: Indian and Northern Affairs Canada.

Clatworthy, S., and Smith, A. 1992. "Population Implications of the 1985 Amendments to the Indian Act: Final Report." Ottawa: Assembly of First Nations.

Cornet, W. 2003a. "Aboriginality: Legal Foundations, Past Trends, Future Prospects." In Aboriginal Rights Litigation, eds. Joseph Magnet and Dwight Dorey, ch.5. Markham, ON: LexisNexis-Butterworths Canada.

- - - 2003b. "First Nation Identities and Individual Equality Rights: A Discussion of Citizenship, Band Membership and Indian Status: Executive Summary Prepared for NAWA.” January 26. Ottawa: National Aboriginal Women's Association.

Deloria, V. 2003. Custer Died for Your Sins: An Indian Manifesto. Norman: University of Oklahoma Press.

Eitzen, E. M. and E. T. Takafuji. 1997. "Historical Overview of Biological Warfare." In Medical Aspects of Chemical and Biological Warfare, eds. F. R. Sidell, E .T. Takafuji and D. R. Franz, 415-23. Washington, DC: Office of the Surgeon General, Boren Institute, Walter Reed Army Medical Center.

Ellinghaus, K. 2009. "Biological Absorption and Genocide: Comparison of Indigenous Assimilation Policies." Genocide Studies and Prevention 4 (1): 59-79. http://dx.doi. org/10.1353/gsp.0.0008.

Erasmus, G. 2003. "Reparations: Theory, Practice and Education.” Paper presented at University of Windsor, Windsor, Ontario, 13 June. http://www.ahf.ca/downloads/ clea-roundtable.pdf.

Fiske, J-A., and E. George. 2006. Seeking Alternatives to Bill C-31: From Cultural Trauma to Cultural Revitalization through Customary Law. Ottawa: Status of Women Canada.

Fontaine, T. 2010. Broken Circle: The Dark Legacy of Indian Residential Schools: A Memoir. Victoria, BC: Heritage House Publishing.

Garroutte, E. M. 2003. Real Indians: Identity and the Survival of Native America. Berkley and Los Angeles: University of California Press. 
Gibbins, R. 1984. "Canadian Indian Policy: The Constitutional Trap." Canadian Journal Native Studies 4: 1-9.

Government of Canada. 1969."Statement of the Government of Canada on Indian Policy presented to the First Session of the Twenty-eighth Parliament by the Honourable Jean Chretien, Minister of Indian Affairs and Northern Development." Ottawa: Department of Indian Affairs and Northern Development.

Groves, R. 2011. "First Nation Identities: Options for the Determination of Indian Status and Band Membership (Draft)." (Document received via Access to Information and Privacy request dated 28 October 2011.)

Haig-Brown, C. 1988. Resistance and Renewal: Surviving the Indian Residential School. Vancouver: Arsenal Pulp Press.

Harper, S. 2008. Government of Canada. "Statement of Apology—to former students of Indian Residential Schools." June 11. http://www.aadnc-aandc.gc.ca/ eng/1100100015644.

- - - 2012. "Speech Delivered at the Crown-First Nations Gathering." January 24. http:// www.aadnc-aandc.gc.ca/eng/1327522021037.

House of Commons. 1999. "Hansard Debates." October 13. http://openparliament.ca/ hansards $/ 2036 /$ ? singlepage $=1$.

Isaac, T. 1993. Pre-1868 Legislation Concerning Indians: A Selected and Indexed Collection. Saskatoon: University of Saskatchewan Native Law Centre.

Jaimes, M. A. 1992. "Federal Indian Identification Policy: A Usurpation of Indigenous Sovereignty in North America." In The State of Native America: Genocide, Colonization, and Resistance, ed. M. Annette Jaimes, 123-38. Boston: South End Press.

Jamieson, K. 1978. Indian Women and the Law in Canada: Citizens Minus. Ottawa: Advisory Council on the Status of Women.

Lauwers, A. E. 2011. "Report of the Paediatric Death Review Committee and Deaths Under Five Committee." http://www.mcscs.jus.gov.on.ca/stellent/groups/public/@ mcscs/@www/@com/documents/webasset/ec090287.pdf.

Lawrence, B. 2004. "Real" Indians and Others: Mixed Blood Urban Native Peoples and Indigenous Nationhood. Lincoln: University of Nebraska Press.

Long, A., L. Little Bear, and M. Boldt. 1982. "Federal Indian Policy and Indian SelfGovernment in Canada: An Analysis of a Current Proposal." Canadian Public Policy 8: 189-99. http://dx.doi.org/10.2307/3550155.

Magnet, J. E. 2003. "Who are the Aboriginal People of Canada?" In Aboriginal Rights Litigation, ed. J. Magnet and D. Dorey, ch. 3. Markham, ON: LexisNexis Canada.

Mann, M. 2005. "Indian Registration: Unrecognized and Unstated Paternity." Ottawa: Status of Women Canada. http://www.lynngehl.com/uploads/5/0/0/4/5004954/ mann_2005.pdf.

Marshall, I. 1996. "A History of the Beothuk." Presentation based on A History and Ethnography of the Beothuk at the Newfoundland Historical Society, St. Johns, 19 September. http://www.mun.ca/rels/native/beothuk/beohist.html. 
MacIntosh, C. 2009. "From Judging Culture to Taxing 'Indians': Tracing the Legal Discourse of the "Indian Mode of Life." Osgoode Hall Law Journal 47: 399-437.

McDonnell, M. A. and Moses, A.D. 2005. "Raphael Lemkin as Historian of Genocide in the Americas." Journal of Genocide Research 7 (4): 501-29. http://dx.doi. org/10.1080/14623520500349951.

Miller, J. R. 1996. Shingwauk's Vision: A History of Native Residential Schools. Toronto: University of Toronto Press.

Milloy, J. 2008. “Indian Act Colonialism: A Century of Dishonour 1869-1969.” Research paper for the National Centre for First Nations Governance. Vancouver: National Centre for First Nations Governance.

Montour, B. 2011. "United Nations Declaration on the Rights of Indigenous Peoples." Speech at the Assembly of First Nations Special Chiefs Assembly 62nd Session, 13 September.

Moses, A.D. 2008. "Empire Colony, Genocide: Keywords and the Philosophy of History." In Empire, Colony, and Genocide: Conquest, Occupation and Subaltern Resistance in World History, ed. A. D. Moses, 3-54. New York: Berghan Books.

Moss, W., and E. Gardner-O’Toole. 1991. "Aboriginal People: History of Discriminatory Laws.” Revised. http://dsp-psd.pwgsc.gc.ca/Collection-R/LoPBdP/BP/bp175-e.htm

National Archives of Canada, Record Group 10, vol. 6810, file 470-2-2, col.7, pp.55 (L-3) and $63(\mathrm{~N}-3)$.

Native Law Centre. 2003. Indian Acts and Amendments 1970-1993: An Indexed Collection. Saskatoon: University of Saskatchewan Native Law Centre.

Natural Resources Canada. 2009. "Aboriginal Languages.” http://atlas.nrcan.gc.ca/site/ english/maps/peopleandsociety/lang/aboriginallanguages/1.

Neu, D. and Therrien, R. 2003. Accounting for Genocide: Canada's Bureaucratic Assault on Aboriginal People. Blackpoint, NS: Fernwood Publishing.

Office of the Auditor General of Canada. 2000-2010. "Status Report of the Auditor General of Canada to the House of Commons." http://www.oag-bvg.gc.ca/internet/English/ parl_lp_e_925.html.

Office of the Correctional Investigator. 2000-2010. "Annual Report of the Office of the Correctional Investigator." http://www.oci-bec.gc.ca/rpt/index-eng.aspx.

Palmater, P. D. 2000. "An Empty Shell of a Treaty Promise: R. v. Marshall and the Rights of Non-Status Indians." Dalhousie Law Journal 23: 102-48.

- - - 2003. "In My Brother's Footsteps: Is R. v. Powley the Path to Recognized Aboriginal Identity for Non-Status Indians?” In Aboriginal Rights Litigation, ed. J. Magnet and D. Dorey, ch. 6. Markham, ON: LexisNexis.

- - . 2011a. Beyond Blood: Rethinking Indigenous Identity and Belonging. Saskatoon: Purich Publishing.

- - - 2011b. "Stretched Beyond Human Limits: Death by Poverty in First Nations." Canadian Review of Social Policy 112: 112-27.

_-_. 2012. "Unbelievable, but Undeniable: Genocide in Canada." Synergy Magazine, March. http://www.synergymag.ca/unbelievable-but-undeniable-genocide-in-canada. 
_-_. 2013. "Matnm Tel-Mi'kmawi: I'm Fighting for my Mi'kmaw Identity." Canadian Journal of Native Studies 33: 147-67.

O’Malley, Kady. 2008. "Pierre Poilievre shows his empathy for residential school survivors." Macleans, June 11. http://www2.macleans.ca/2008/06/11/pierre-poilievre-showshis-empathy-for-residential-school-survivors.

Paul, D. N. 2007. We Were Not the Savages: Collision Between European and Native American Civilizations. 3rd ed. Blackpoint, NS: Fernwood Publishing.

Paul, P.1990. "Bill C-31: The Trojan Horse: An Analysis of the Social, Economic and Political Reaction of First Nations People as a Result of Bill C-31." Unpublished thesis, University of New Brunswick.

- - - 1999. "The Politics of Legislated Identity: The Effect of Section 6(2) of the Indian Act in the Atlantic Provinces." Amherst, NS: Atlantic Policy Congress of First Nations Chiefs.

Public Health Agency of Canada. 2007. "Special Committee Report of the Canadian Tuberculosis Committee: Tuberculosis Among the Aboriginal Peoples of Canada, 2000 to 2004." http://www.phac-aspc.gc.ca/publicat/2007/tbcan04/tbaboriginaleng.php

Reagan, P. 2010. Unsettling the Settler Within: Indian Residential Schools, Truth Telling and Reconciliation in Canada. Vancouver: UBC Press.

Royal Commission on Aboriginal Peoples [RCAP]. 1996. Report of the Royal Commission on Aboriginal Peoples. Ottawa: Minister of Supply and Services.

Short, D. 2010. "Cultural Genocide and Indigenous Peoples: A Sociological Approach." The International Journal of Human Rights 14 (6): 833-48.

Smith, A. 2005. Conquest: Sexual Violence and American Indian Genocide. Cambridge: South End Press.

Steinbeck, J. 2002. America and Americans and Selected Nonfiction. New York: Viking Press. Sullivan, R. 2007. Statutory Interpretation. 2nd ed. Toronto: Irwin Law.

Titley, B. 1986. A Narrow Vision: Duncan Campbell Scott and the Administration of Indian Affairs in Canada. Vancouver: UBC Press.

Trevithick, S. 1998. "Native Residential Schooling in Canada: A Review of Literature." The Canadian Journal of Native Studies 18: 49-86.

van Krieken, R. 2004. "Rethinking Cultural Genocide: Aboriginal Child Removal and Settler-Colonial State Formation." Oceania 75: 125-51.

Venne, Sharon H. 1981. Indian Acts and Amendments 1868-1975: An Indexed Collection. Saskatoon: University of Saskatchewan Native Law Centre.

Wolfe, P. 2006. "Settler Colonialism and the Elimination of the Native." Journal of Genocide Research 8 (4): 387-409. http://dx.doi.org/10.1080/14623520601056240.

Woolford, A. 2009. "Ontological Destruction: Genocide and Aboriginal Peoples in Canada." Genocide Studies and Prevention: An International Journal 4 (1): 81-99. http:// dx.doi.org/10.1353/gsp.0.0010. 


\section{Legislation}

An Act For The Gradual Enfranchisement of Indians, the Better Management of Indian Affairs, and to Extend the Provisions of the Act $31^{\text {st }}$ Victoria, S.C. 1869, c.6.

Bill C-27, First Nations Financial Transparency Act, $1^{\text {st }}$ sess., $41^{\text {st }}$ Parliament, 2011. http://www.parl.gc.ca/About/Parliament/LegislativeSummaries/bills_ ls.asp? Language $=\mathrm{E} \& \mathrm{ls}=\mathrm{c} 27 \& \operatorname{Parl}=41 \&$ Ses=1\&source=library_prb.

Bill C-428, Indian Act Amendment and Replacement Act, $1{ }^{\text {st }}$ sess., $41^{\text {st }}$ Parliament, 2011. http:// www.parl.gc.ca/LegisInfo/BillDetails.aspx?billId=5618344\&Mode=1\&Language $=\mathrm{E}$

Bill S-2, Family Homes on Reserve and Matrimonial Interests or Rights Act, $1^{\text {st }}$ sess., $41^{\text {st }}$ Parliament, 2011. http://www.parl.gc.ca/content/hoc/Bills/411/Government/S-2/S2_3/S-2_3.PDF.

Bill S-6, First Nations Elections Act, $1^{\text {st }}$ sess., $41^{\text {st }}$ Parliament, 2011. http:// www.parl.gc.ca/About/Parliament/LegislativeSum maries/bills_ ls.asp $?$ ls $=$ s6\&Parl=41\&Ses $=1 \&$ source $=$ library_prb\&Language $=\mathrm{E}$.

Bill S-8, Safe Drinking Water for First Nations Act, $1^{\text {st }}$ sess., $41^{\text {st }}$ Parliament, 2011. http://www.parl.gc.ca/About/Parliament/LegislativeSummaries/bills_ ls.asp? Language $=\mathrm{E} \& \mathrm{l} s=\mathrm{s} 8 \& \mathrm{Parl}=41 \& \mathrm{Ses}=1 \&$ source=library_prb.

Constitution Act, 1867 (U.K.), 30 \& 31 Vict., c.3.

Constitution Act, 1982, being Schedule B to the Canada Act, 1982 (U.K.), 1982, c.11.

Indian Acts, 1876-2010.

Indian Act, R.S.C. 1985, c. I-6 [Bill C-3].

Indian Act, R.S.C. 1985, c. I-5, as am. By R.S.C. 1985, c.2 (1st Supp.) [Bill C-31].

Indian Act, R.S.C. 1985 c. I-5.

United Nations Convention on the Prevention and Punishment of the Crime of Genocide. 9 December 1948.

United Nations Declaration on the Rights of Indigenous Peoples, UNGA, 62nd Sess. UN Doc. A/RES/61/295, 13 September 2007.

\section{Court Cases}

Sharon McIvor and Jacob Grismer v. Canada, Communication Submitted for Consideration under the First Optional Protocol to the International Covenant on Civil and Political Rights, United Nations Human Rights Committee (24 November 2010).

Lavell v. Canada (Attorney General); Isaac v. Bedard (1974), S.C.R. 1349.

McIvor v. Canada, [2009] BCCA 153 [McIvor], [2007] 2 C.N.L.R. 72.

R. v. Powley. 2003. 2 S.C.R. 207.

Sandra Lovelace v. Canada, Communication No. R.6/24, U.N. Doc. Supp. No. 40 (A/36/40) at 166 (1981). 